\title{
Jesus en vroue
}

Yolanda Dreyer
Tydelik-deeltydse dosent: Departement Nuwe-Testamentiese Wetenskap (Afd A)
Universiteit van Pretoria

Jesus and women

The patriarchal view of reality in first-century Mediterranean culture was based on a disparity between man and woman. It was a hierarchical system in which man was considered to be above woman, as God is above human beings. In the world of Jesus a woman would be represented before God by the patriarch. This article illustrates how Jesus' words and deeds did not mirror the values of his culture as far as the importance and role of the patriarchal family were concerned. Jesus' words and deeds were unconventional within a strict purity system. Jesus used family imagery when speaking about the kingdom of God, but he meant a different type of family than the physical family according to cultural conventions. His non-patriarchal interaction with women was an example and a consequence of his culture critique.

\section{INLEIDING}

Die ondersoek na die historiese Jesus het aangetoon dat Jesus onkonvensioneel opgetree en gepraat het binne 'n streng hiërargiese reinheidstruktuur. Hy het byvoorbeeld 'n ander soort familie as die biologiese bedoel toe $\mathrm{Hy}$ verduidelik het wie tot die 'koninkryk van God' behoort en Hy het op 'n nie-patriargale wyse met vroue en kinders omgegaan (vgl bv Mark 3:31-35). Rudolf Bultmann ([1960] 1965:11) som sy verstaan van die kern wie Jesus was en die saak waarvoor Hy gestaan het, soos volg op:

Mit einiger Vorsicht also wird man über das Wirken Jesu Folgendes sagen können. Charakteristisch für ihn sind Exorzismen, der Bruch des Sabbatgebotes, die Verletzung von Reinheitsvorschriften, die Polemik gegen die jüdische Gesetzlichkeit, die Gemeinschaft mit deklassierten Personen wie Zollnern und Dirnen, die Zuneigung zu Frauen und Kindern; auch ist zu erkennen, daß Jesus nicht wie Johannes der Täufer ein Asket war, sondern gerne aB und ein Glas Wein trank. Vielleicht darf man noch hinzufügen, daß er zur Nachfolge aufrief und eine kleine Schar von Anhängern - Männern und Frauen - um sich sammelte (my beklèmtoning). 
In 'n ander artikel het ek ingegaan op die personaliteit van vrou-wees binne die hiërargiese reinheidstruktuur in die eerste-eeuse Mediterreense kultuur (kyk Dreyer 1999). Wat Jesus se simpatie met die lot van vroue binne hierdie struktuur betref, is daar geleerdes (kyk o a Kathleen Corley 1997) wat van mening is dat Jesus nie in hierdie opsig so uniek was in die antieke tyd nie, en dat ons daarom nie te veel in ons teologiese besinning van hierdie egalitêre gesindheid moet maak nie. Binne die konteks van Joodse, Griekse en Romeinse literatuur tref ons egter so 'n gesindheid naas Jesus self, net by Plato (en dan slegs in beperkte sin), Musonius Rufus, Seneca (ook in 'n baie beperkte sin) en Paulus aan (kyk Klassen 1984:185-206). Paulus bou ongetwyfeld voort op die Jesus-tradisie. Enersyds was Jesus se siening die radikaalste van hulle almal en andersyds was sy visie deel van 'n koherente anti-hiërargiese perspektief wat onafskeidelik deel van sy 'teologie' gevorm het. In sy boek Honest to Jesus: Jesus for a new millennium, stel Robert Funk (1996:41) hierdie 'teologie' só:

God's domain was for Jesus something already present. It was also something to be celebrated because it embraces everyone - Jew, gentile, slave, male, female. In God's domain, circumcision, keeping kosher, and sabbath observance are extraneous. The kingdom represents an unbrokered relationship to God: temple and priests are obsolete (my beklemtoning).

In my doktorale proefskrif het ek na hierdie oortuiging dat enige mens, afgesien van ouderdom, geslag of herkoms, 'n direkte en anti-hiërargiese toegang tot God het en met outentisiteit in verhouding met God kan staan, die Jesus-saak genoem (kyk Dreyer 1998:90-91). Jesus was vir die vroegste Christene die menslike gesig van die liefde van God. Hierdie 'beeld van God' was 'n radikale herdefinisie van die beeld van God in die gangbare kultuur. Kultuur orden in hiërargiese strukture. Jesus as God-met-ons rig die gelowige op 'n Godsbeeld waar hiëragiee nie die verhouding met God determineer nie. 'n Prominente Jesus-navorser, Marcus Borg, verwys soos volg in (die Nederlandse vertaling van) sy boek, Als met nieuwe ogen: De historische Jezus en waar het op aan komt in het geloof vandaag, na die voortgesette invloed van dié Jesus-saak in die res van die Nuwe Testament en in die teologiese tradisie daarna:

De inclusiviteit van de Jezusbeweging wordt voortgezet in de vroegchristelijke beweging, zoals we horen uit beschrijvingen in andere delen van het Nieuwe Testament. Het was een van de meest in het oog lo- 
pende eigenschappen van de beweging ... Ook de beroemde woorden van Paulus negeren de wereld van reinheid en culturele grenzen en drukken dezelfde inclusiviteit uit: 'In Christus is noch Jood noch Griek, slaaf noch vrije, man noch vrouw.' Paulus kondigt hier geen abstract ideaal aan; dit vers laat de nieuwe maatschappelijke realiteit van de beweging zelf zien

(Borg [1994] 1995:76; my beklemtoning)

Om die plek van vroue binne die konteks van die Jesus-saak te begryp, is dit egter nodig om eers insig te verkry in die oos-Mediterreense 'wêreld van reinheid' en 'kulturele grense' waarbinne Jesus opgetree en gepraat het.

\section{JESUS EN DIE REINHEIDSIDEOLOGIE}

Die Jesus van die geskiedenis was nie ' $n$ a-kulturele, universele wese nie, maar 'n mens van sy tyd - ' $n$ Jood in Palestina aan die begin van die eerste eeu. Die doel van hierdie artikel is nie om in te gaan op die detail argumente van historiese Jesus-navorsers waarom sekere woorde en optredes teruggevoer sou word na Jesus en ander na die interpretasies van die vroegste Christene nie. Ek het wel daarvan kennis geneem dat sekere van die Jesus-woorde en -optredes deur die meeste historiese Jesus-navorsers nouliks as historiese materiaal gereken kan word (kyk Funk \& Hoover 1993; Funk 1998). My uiteensetting van die Jesus van die geskiedenis geskied binne die raamwerk van materiaal wat breedweg as histories geag word. Waar daar van dié materiaal is wat gekleur is deur ' $n$ evangelis of ander Bybelskrywer, sal ek dit genuanseerd só aandui. In sommige gevalle waar historici onseker is oor die historiese outentisiteit van materiaal, maar dit wel met my Jesus-beeld korreleer, het ek vryelik en sonder nuanse daarvan gebruik gemaak.

Jesus het gelewe binne 'n patriargale sosiale sisteem waar die vader die hoof van die familie was en as sodanig deur die wet erken is. Die patriarg was ook aanvaar as deelnemende lid van die stad/staat of koninkryk (vgl Jacobs-Malina 1993:1). Dit is met ander woorde 'n lewe binne eerste-eeuse Mediterreense denkpatrone. Die vader het die belangrike waardes van sy samelewing geken, soos eer en skande, die belang van die groep bo dié van die individu, die belangrikheid van die familiesisteem, die opvattings oor wat volgens die reinheidsisteem van die tyd behoorlik en toelaatbaar was en wat nie, die besitregsisteem, en die plek en rol van vroue en kinders.

In baie opsigte blyk uit die evangelies hoe Jesus binne hierdie betekenissisteme van sy kultuur gefunksioneer en dit gehoorsaam het. In ander opsigte het Hy afgewyk van 
wat in sy kultuur as reg en goed beskou was. Dit is logies dat mense sal optree volgens die norme en standaarde wat hulle kultuur voorskryf. Dit kom gewoon outomaties. Iemand wat só ingepas het in konvensionele patrone, is aanvaar as 'n persoon met eer en status binne die samelewing. Wanneer Jesus egter afgewyk het van die normale patrone van sy kultuur, was Hy nie meer in pas met die bestaande en vanselfsprekende nie. Sy optrede was dan doelbewus anders en daarom ryk aan betekenis. Dit is van belang om te vra wár en hóé Jesus ten opsigte van die leefwêreld in terme waarvan vroue se waarde, ruimte en persoonskap bepaal was, bewustelik afgewyk het van die aanvaarde norme van sy kultuur.

Jesus is volgens Lukas 2:27 in gehoorsaamheid aan die voorgeskrewe reinheidsreëls op die agtste dag besny. Hy het onrein geeste uitgedryf (kyk o a Mark 1:21-28; vgl Funk 1998:57). Jesus het melaatses genees en hulle dan beveel om alles te doen wat die wet vereis (kyk o a Luk 5:12-15; Mark 1:40-43; vgl; Crossan 1992:177-190; Funk 1998:61, 280). Hierdie optrede van Jesus dui aan hoe Hy as 'n persoon van sy tyd en kultuur gehoor gegee het aan die reinheidsisteem waarvolgens die kontemporêre samelewing die lewe georden en aan die ander kant het Jesus 'n ('onrein') menstruerende vrou toegelaat om aan Hom te raak (Luk 8:42b-43; vgl Funk 1998:298). Volgens Lukas 7:11-17 het Hy selfs aan die baar geraak waarop die lyk van die weduwee van Nain se seun gelê het en aan die hand van Jaïrus se dogter gevat wat volgens die omstanders reeds dood was (Luk 8:40-42a, 49-55; vgl Funk 1998:298-299). Dit sou beteken het dat Jesus ook onrein geword het en die voorgeskrewe wasrituele moes volg om weer kulties rein te word. Dit word egter nie berig nie - inteendeel Jesus en sy dissipels het doelbewus die wasrituele verontagsaam (kyk Mark 7:1-5; vgl Funk 1998: 94).

Die gevolge van hierdie oortredings van die reinheidsreëls het egter uitgeloop op die genesing van die vrou met bloedvloeiing en die getuienis dat die seun en dogter uit die dood opgestaan het (vgl Countryman [1988] 1989:77-78). Jesus het dikwels mense wat fisies gestrem was, en dus volgens die reinheidsvoorskrifte nie sosiale betrekkinge met die lede van God se volk kon handhaaf nie, of mense wat uit die tempel uitgesluit was op grond van 'n gebrek aan 'heelheid' (Malina 1993:172), genees. Hierdie genesings het dus heling geïmpliseer. Heling het neergekom op resosialisering, dit wil sê op akkommodering in die gesinslewe en daarom ook op toegang tot God. Anders as wat die geval was met die Fariseërs, is dit duidelik dat hulpverlening aan fisies gestremde mense vir Jesus belangriker was as die strenge nakoming van die reinheidsvoorskrifte. Jesus het nie met Angst opgetree teenoor hulle wat volgens die Joodse definisie as onrein beskou was nie. Hierdie onbevangenheid is later in die vroeg-Christelike kerk voortgesit, veral ten opsigte van die verwelkoming van (onrein) nie-Jode in die geledere van die kerk. Ook die reinheidsvoorskrifte ten opsigte van voedsel is in die vroeg-Christelike kerk heelwat afgeskaal en het later heeltemal verdwyn. 
Volgens die reinheidsisteem is mense geklassifiseer in terme van heilig tot minder heilig en is daar aan hulle dienooreenkomstig bepaalde plek in die samelewing toegeken (kyk o a Funk 1998:210-211; Van Eck 1995:196-206;). Hierdie klassifikasie het bepaal met wie 'n mens mag sosialiseer en tot op watter vlak, en met wie nie. Jesus het egter nie sy dissipels gekies uit die geledere van die mees wetsgehoorsame Jode nie (kyk Luk 5:27-28; vgl Funk 1998:282). Hy het vryelik gesosialiseer met tollenaars en sondaars (kyk o a Luk 5:29-32). Hy het gebots met die Fariseërs oor tafelreinheid (kyk Mark 7:1-5) en het die 'sondares' wat sy voete was tydens 'n ete in Simon die Fariseër se huis aanvaar (kyk Luk 7:36-50; vgl Funk 1998:292). Jesus het 'n ander lig gewerp op reinheid, deurdat Hy volgens die Spreuke-evangelie Q (kyk Luk 11:37-54; Matt 23: 1-36; vgl Funk 1998:313-314) die Fariseërs vergelyk het met onder andere witgepleisterde grafte. Hiermee word gesê dat die sogenaamde 'reines' ander mense kontamineer sonder dat hulle dit self agterkom (Luk 11:44). By geleentheid het Jesus ook 'n storie vertel waarin 'n Fariseër met 'n 'onrein' tollenaar vergelyk is, en slegter as die tollenaar en ander 'onreines', soos owerspeliges, daarvan afkom (kyk Luk 18:9-14a; vgl Funk \& Hoover 1993:369).

Die vraag is dan wat dit sou beteken dat Jesus op dié wyse afgewyk het van die reinheidsvoorskrifte van sy tyd en kultuur? Jesus het wel in die breê die reinheidsvoorskrifte aanvaar, soos dit in die Ou Testament uiteengesit is en deur die mense van sy kultuur nagekom is. Maar dit lyk asof $\mathrm{Hy}$ in die nakoming van hierdie konvensies nie kon aanvaar dat eie belange nagestreef en ander uitgesluit is uit die betoning van liefde nie. Hy kon nie instem dat konvensies gebruik word om toegang tot God te versper nie. Binne ' $n$ reinheidsisteem het reinheidvoorskrifte eerder ten doel om toegang tot God moontlik te maak. Dit moet nie maar net gaan oor die meganiese instandhouding van 'n sisteem nie (Malina 1993:173). Klaarblyklik is die saak wat Jesus wou tuisbring, die evangelie dat God se genade genoeg is (Countryman 1989:78-79). So gesien, kan die uiterlike rituele en die nakoming van gebruike eerder outentieke lewe belemmer as bevorder. Israel se kultuurmaatreëls leer dat die streng handhawing van reinheidsgebruike toegang tot God moontlik maak. Jesus het egter geleer dat dit nie 'n mens se etniese oorsprong, geslag, natuur, siekte, kos of enige biologiese funksie van die menslike liggaam is wat toegang tot God versper nie (vgl Jacobs-Malina 1993:38). Volgens Jesus lê die slegte dinge nie inherent aan die uiterlike posisie waarin die mens gebore is nie, maar kom dit uit die hart van die mens: onkuisheid, diefstal, moord, owerspel, hebsug, kwaadwilligheid, bedrog, losbandigheid, afguns, kwaadpratery, hoogmoed en ligsinnigheid (kyk Mark 7:14-23; vgl Funk \& Hoover 1993:69). Daarom, leer Jesus, is dit slegs deur die genade van God moontlik dat die mens toegang tot God verkry. 
Die feit dat die Markus-evangelie berig dat Jesus reinheidsvoorskrifte eenkant toe geskuif het ten gunste van die metaforiese konsep 'reinheid van hart', beteken dat Jesus nie verontreiniging gevrees het nie. Hy het onreinheid met sy eie krag oorwin. Die nuwe reinheid waarvan Jesus praat, werk op 'n ander vlak. Dit gaan nou nie meer om die corsake van onreinheid te vermy nie, maar om die gesindheid en bedoeling wat agter 'n daad lê (kyk Countryman 1989:86, 87; vgl Malina 1993:173). Matteus weer, begin heel tradisioneel met 'n geboorterekord van Jesus wat ten doel het om sy suiwer afstammelingskap van Abraham en Dawid aan te dui. Tog is die geslagsregister radikaal ontradisioneel deurdat dit vier vroue insluit. Die vroue is ook nie die toonbeeld van reinheid en suiwerheid nie. Hulle is of nie-Jode, of betrokke by die een of ander oortreding van die seksuele kode. Matteus beskou die nie-Joodse, sondige vrou as belangrike medewerker aan God se verlossing. Hoewel sy Evangelie op die oog af meer tradisioneel Joods voorkom, is dit ewe radikaal as Markus wanneer dit kom by die Joodse reinheidsgebruike: reinheid van hart, en nie fisieke reinheid nie, staan sentraal (Countryman 1989:90-92).

Die Johannes-evangelie is selfs nog verder verwyderd van die Joodse reinheidsisteem as dié van die ander evangeliste. Hierdie evangelie beklemtoon hoe dit wat as onrein beskou word instrumente kan wees om by God uit te kom (Countryman 1989: 93-94). 'n Voorbeeld hiervan is die Samaritaanse vrou van twyfelagtige reputasie wat die verkondiger van die evangelie en die eerste suksesvolle sendeling word (vgl Joh 4:4-26). Ook word in die evangelie van Johannes (kyk Joh 7:53-8:11) berig hoe Jesus 'n vrou wat van owerspel aangekla word, te hulp kom. Hoewel hierdie verhaal tekskrities gesien nie in die gebruiklike grondteks voorkom nie, bly dit opvallend dat latere kopieerders van manuskripte, wat nie van hierdie historiese nie-outentisiteit bewus was nie, hierdie verhaal klaarblyklik gesien het as baie tipies van Jesus se gesindheid en dit daarom nie uit die Johannes evangelie weggelaat het nie (kyk Metzger 1971:219-222). Die tempel was die sentrum van reinheidswette en -voorskrifte - of dit nou die kultus in Jerusalem of op die Gerizim was (kyk Joh 4:19). In die Johannes-evangelie verwys Jesus implisiet na Homself as die nuwe tempel. As die 'nuwe tempel' verklaar Jesus in die teenwoordigheid van 'n ('onrein') Samaritaanse vrou die reinheidswette en -rituele ongeldig, want God moet voortaan aanbid word in Gees en in waarheid (kyk Joh 4:2125). God word nie langer deur mensepogings gevange gehou binne die grense wat die godsdienstige elite neergelê het nie (vgl Jacobs-Malina 1993:98).

Dit is egter nie net die Fariseërs wat onder skoot kom nie (kyk Countryman 1989: 95). Die evangeliste trek te velde teen elke soort godsdiens wat mense se waarde beoordeel volgens eksterne norme. Hierdie soort fariseïsme kom onder Christene voor net soveel as elders. Dit gaan daaroor dat eie godsdienstige suiwerheid verhef word ten 
koste van ander mense. In die lig van die Jesus-saak word die Christelike etiek egter gebaseer op die begrip reinheid van hart. Die begrip kan gedefinieer word as die gewilligheid om die naaste te respekteer en die onwilligheid om die naaste skade aan te doen (Countryman 1989:140). In die Christelike etiek val die klem dus sterk op die naaste (kyk Malina 1993:174).

As reinheidsvoorskrifte ten doel het om toegang tot God moontlik te maak, en as God, tot wie 'n mens toegang wil hê, die welsyn van mense as hoogste prioriteit het, is die korrekte interpretasie van reinheidsvoorskrifte dié een wat voorrang verleen aan goeie verhoudings met die naaste. 'n Regverdige lewe getuig dus van goeie interpersoonlike verhoudings met almal in die samelewing: tussen mens en God en tussen mens en medemens. Die Joodse wet was daarop gemik dat Joodse mans hulleself kon afsonder sodat hulle die reinheidsvoorskrifte kon nakom. Die reinheidsvoorskrifte in hierdie kultuur is ontwerp om vroueliggame, -bloed, swangerskap en die proses van geboorte weg te hou van mans. Wat tot die vrou behoort, is beskou as die antitese van die heilige, ook dus van God (vgl Jacobs-Malina 1993:27).

Jesus het hierdie skeiding tussen geslagte radikaal opgehef. Hy het sterk beswaar gemaak teen die 'hardheid van harte'. Dit geld vir die mans by die sinagoge wat nie deernis gevoel het vir die man met die verdorde hand nie (Mark 3:1-6; vgl Funk 1998: 68-69). Dit geld volgens Matteus ook vir mans wat hulle vrou met 'n skeibrief wegstuur en geen deernis het met die situasie wat dit vir die vrou veroorsaak nie (Matt 19: 3-8). Moses (die Tora - kyk Esra 10; Neh 10) het wel die hardheid van harte as 'n werklikheid aanvaar, maar Jesus nie. Jesus wou die toestand wat God daargestel het, herstel. Daarom verwys Jesus terug na die skepping en verklaar: 'Dit is oor die hardheid van julle harte dat hy hierdie bepaling vir julle gemaak het. Maar van die begin af, van die skepping af, het God hulle man en vrou gemaak. Daarom sal 'n man sy pa en ma verlaat en saam met sy vrou lewe, en hulle twee sal een wees, sodat hulle nie meer twee is nie, maar een. Wat God dan saamgevoeg het, mag 'n mens nie skei nie' (Mark 10:5-9).

Volgens Dianne Jacobs-Malina (1993:27) het die skeiding van wat God saamgevoeg het, begin toe die kultuur sigself georganiseer het rondom die besnydenis en dit geinterpreteer het as die Goddelike bevestiging van manlike status en posisie. DodsonGray (1982:26) stel dit sterk:

When the holy space of a religion is sacred for male sexuality (as in the marking of the covenant upon the male phallus in circumcision), and sacred for blood sacrifice presided over by males; and when that same holy space is contaminated by female blood and female fertility (as in 
menstruating and in giving birth), we are dealing with a male fertility cult, no matter what its other lofty spiritual insights may be.

God het bedoel dat man en vrou een sal wees. Maar volgens mense se kultuurbeskouing is die opinie gehuldig dat vrouegeslagtelikheid en -bloed die man se toegang tot God sou versper. Daarom tref die kultuur maatreëls in die vorm van reinheidsvoorskrifte wat man en vrou skerp van mekaar afskei. Om verder gewoon weg te doen met die vrou in die vorm van egskeiding, is volgens die kultuur vir die man 'n opsie. Hy hoef geen gewetenswroeging daaroor te hê nie. Maar Jesus het dieselfde beperking op die man geplaas as wat die kultuur op die vrou plaas, naamlik: geen egskeiding nie (Jacobs-Malina 1993:28).

Ons weet dat, ook wat egskeidingsmaatreëls betref, daar ' $n$ historiese en kulturele afstand tussen die Nuwe Testament en vandag is (vgl o a Countryman 1989:143). Dit beteken dat hedendaagse lesers van die Nuwe Testament moet waak dat hulle nie die antieke tekste lees en afleidings maak vanuit hulle eie ervaring en tradisie nie. In betrokke hermeneutiek, soos in die kommunikatiewe handelingsteorie, gaan dit nie bloot om die intolk van 'n vorige boodskap in die hede nie - allermins om die blote oordrag van kultuurmaatreëls. Dit gaan om 'n kritiese lees van die Bybel - om die blootlegging van motiewe wat outentieke lewe voor God versper. Daarom moet hedendaagse lesers van die Bybel eers die huidige (ook kerklike) konvensies rondom byvoorbeeld huweliksluiting en egskeiding opskort, 'so that one does not forbid Scripture to speak things unheard of in our narrow experience. One thing it so speaks is the end of the ethic of physical purity' (Countryman 1989:143).

In Handelinge 15 word die minimum reinheidsreels voorgeskryf wat dit moontlik gemaak het vir nie-Joodse Christene om 'in Christus' met Joodse Christene saam te verkeer. Paulus het geoordeel dat die reinheidsvoorskrifte van Israel vir gelowiges in Christus nie meer bindend is nie. Wat mense betref, is hulle of in Christus, of nie. Die simboliese oorgang van buite na binne word aangedui deur die doopritueel. Die manier waarop 'n Christen aan God 'offer', is deur gebed en dienswerk. Daar is nie meer ' $n$ onderskeid tussen heilige tye en ander tye nie. Alle tye is heilig vir die wat in Christus is (vgl o a Malina 1993:176-178).

Paulus se beginsel is dat ' $\mathrm{n}$ mens nie moet doen wat teen sy of haar eie gewete ingaan nie. As 'n mens se gewete volgens hierdie 'beginsel' as gevolg van jou gelowige binding aan Christus verander, dan oordeel Paulus dat wat vroeër onrein was, nou aanvaarbaar geword het. Die konsekwensie is dat 'n persoon wat teen sy of haar gewete ingaan, nie 'n reinheidsvoorskrif oortree nie, maar sonde doen (kyk Country- 
man 1989:104). Vry van sodanige voorskrifte, kry 'rein' en 'onrein' 'n ander betekenis: dit dien nie meer as ' $n$ reguleringspoging om toegang tot God moontlik te maak of te versper nie. Wat onrein is vir ' $n$ persoon, is wat die persoon self as onrein beskou sonder om 'n oordeel uit te spreek oor die verhouding tussen God en 'n ander mens met ander ' $n$ ander gewete. Dit beteken nie dat kultuurmaatreels, $\infty$ k ten opsigte van rein of onrein, vir mense in Christus nou geen bindingskrag meer het nie. Daarom vind 'n mens steeds in die Nuwe Testament 'n veroordeling van wat volgens die kulturele norme van die tyd nie as aanvaarbaar beskou word nie. Ook die interaksie van Christene met hulle sosiale omgewing vereis dat Christene hulle hou aan gedrag wat in die Grieks-Romeinse wêreld beskou is as eerbaar en ordentlik (kyk Malina 1993:179).

Ons moet egter raaksien dat, in die algemeen gesien, Paulus (en die Pauliniese tradisie) besef het dat die konsep 'onreinheid' in die kultuur gefunksioneer het as instrument om iemand anders te etiketteer en te benadeel. Countryman (1989:109) noem dit 'competitive greed for influence in the community or for sexual property.' In so 'n kultuur is die begrippe 'reinheid' en 'heiligheid' uitruilbaar. Dit is begrippe wat as gevolg van kulturele internalisering ook op die kerk as geloofsgemeenskap van toepassing gemaak is. Daarom vind ' $n$ mens in die Pauliniese tradisie die opvatting dat, solank 'n persoon binne die Christelike groep bly, hy of sy as as 'heilig'/ 'rein' (wat pas by God) beskou is. Die Nuwe-Testamentikus, Jouette Bassler (1982:187), wys daarop dat, hoewel daar by God geen voorkeur is nie en enigeen in Jesus. Christus toegang het tot God, die gemeenskap van gelowiges wel van ongelowiges onderskei is.

'Heilig'/'rein' of 'goddeloos'/'onrein' word so diskriminerende kategorieê wat tussen 'gelowig' en 'ongelowig' onderskei. Vanweẽ die kulturele opvatting oor groepsidentiteit maak Paulus die afleiding dat almal wat in 'n gelowige persoon ingebed is, ook 'heilig' is. Dit geld vir sowel minderjarige kinders as 'n ongelowige huweliksmaat. Wat belangrik is om raak te sien, is dat geslag in die Pauliniese tradisie nie meer dieselfde rol speel as in die patriargale sisteem nie. In die patriargale sisteem kon slegs vrouens en kinders in mans ingebed wees en nie andersom nie. Robert Atkins (1991: 168) wys in sy boek, Egalitarian community: Ethnography and exegesis, daarop dat ons by Paulus, voortspruitend uit sy gegrepenheid deur die Jesus-saak, 'n kultuurkritiese standpunt vind wat kultuurmaatreëls in teologiese lig relativeer.

In die vroeg-Christelike kerk gaan dit om egalitariteit tussen gelowiges - nie meer om die belang van die patriarg as sodanig nie. As die gelowige ' $n$ vrou is, word haar man en kinders beskou as by haar ingebed en daarom deur haar 'geheilig' en vir God 'afgesonder'. Die heiligheid van die Christelike groep word dus beskou as meer effektief as die onreinheid buite die groep. Dit is die gevolg van God se voortdurende teen- 
woordigheid in die lewe van gelowiges - 'n teenwoordigheid wat moontlik gemaak is deur God se koms na die mense toe in en deur Jesus van Nasaret. Alle gelowiges is mense in Christus. Kerkwees binne die Mediterreense kultuur kom steeds daarop neer dat die verbondenheid met die groep steeds die hoogste prioriteit geniet. Eties het dit die implikasie dat hierdie verbondenheid tot uitdrukking kom in die sorg wat gelowiges op 'n egalitêre wyse vir mekaar het. In 1 Korintiërs 13 byvoorbeeld beteken liefde verbondenheid aan die groep en sorg vir die lede van die groep (Malina 1993:179-80).

Reinheidsvoorskrifte gee aan elke mens of ding 'n plek. Hierdie orde gee sin aan die menslike bestaan. 'n Onderafdeling van reinheidvoorskrifte het te doen met heiligheid en onheiligheid, dus wat afgesonder is vir God en wat nie. Die vroeë Christene het 'n ander siening van God en God se heiligheid as die Joodse godsdiens gehad. Hierdie siening het voortgespruit uit hulle ervaring van Jesus en sy kritiek op die hiërargiese sisteem van sy tyd. Op grond hiervan het daar dus 'n herevaluering gekom van wat in die kultuur beskou was as heilig. Hieruit vloei nuwe reëls en voorskrifte vir wat heilig is. Die kern van hierdie nuwe visie is direkte toegang tot God (kyk Ef 2: 17-18), soos moontlik gemaak deur Jesus (Malina 1993:181).

\section{JESUS EN DIE PATRIARGALE FAMIIIESISTEEM}

Die patriargale siening van die werklikheid in die eerste eeuse Mediterreense wêreld is gebaseer op die ongelykheid tussen man en vrou. Dit is 'n hiërargiese sisteem waarin die man bo die vrou geag word, soos God bo mense is. God regeer oor die hemele soos die mens regeer oor die natuur. Sulke vergelykings en vele meer bevestig telkens weer die meerderwaardigheid van die man en die minderwaardigheid van die vrou, sowel as die onoorbrugbare kloof tussen man en vrou wat daar in 'n patriargale kultuur soos dié in die leefwêreld van die Bybel bestaan (Jacobs-Malina 1993:75).

Daarom is dit opmerklik dat Jesus se optrede en woorde nie dieselfde waardes weerspieël as die kultuur van sy tyd ten opsigte van die belangrikheid, plek en waarde van die patriargale familie nie. Jesus is bekend daarvoor dat Hy gesosialiseer en vriende gemaak het met 'sondaars', en dat Hy in plaas van op 'n fisiese vader (wat opvallend geen rol in sy lewe gespeel het nie; kyk Van Aarde 1998a) sy vertoue op God as sy vader geplaas het. Hierdie houding het die patriargale waardes van sy tyd ondermyn (kyk Van Aarde 1997:468-469). Reeds sy geboorte dui op 'n breuk met die 'huis van sy vader'. Dit kan gesien word in Matteus se vertelling van Jesus se maagdelike verwekking, wat nie dieselfde strekking het as dié van die vroeë kerk sedert die tweede ceu n C nie (kyk o a Coun-tryman 1989:170). In byvoorbeeld die tweede-eeuse Protevangelium van Jakobus is Maria se maagdelikheid ' $n$ aanduiding van haar reinheid en ongeskondenheid, wat haar dus 'n bruikbare instrument maak vir hierdie groot werk van God (kyk Hock 1995:15). 
By Matteus weer gaan dit daarom dat Jesus nie fisies verbonde is aan 'n patriarg, 'n familiehoof en sy huis nie. Hierdie skeiding van die familie sal Jesus ook later van sy volgelinge verwag. 'For his followers, family was no longer a central and unquestioned value' (Countryman 1989:173). In die dokumente (of tradisies daarin) wat teruggevoer kan word naaste aan die historiese Jesus, soos byvoorbeeld Paulus, die Spreuke-evangelie Q (wat agter Matteus en Lukas 1e), die Tomas evangelie (gedeeltelik beskikbaar in enkele Griekse fragmente maar in geheel in Kopties vertaal) en die Markus evangelie, is daar geen verwysing na 'n figuur soos Josef nie (kyk Van Aarde 1998b). Van Aarde (1997) skryf Jesus se a-patriargale houding, sy simpatieke optrede teenoor vroue en kinders en sy vertroue in God as sy $A b b a$ daaraan toe dat hy as vaderlose kind grootgeword het.

In 'n patriargale sisteem ontvang persone hulle lewe, identiteit en lewenspatroon van die vader (vgl Jacobs-Malina 1993:89). In Markus 6:3 word Jesus nie 'seun van Josef' genoem nie, maar 'seun van Maria'. Die koppeling van 'n manspersoon aan sy ma, in plaas van sy pa, verwys in die Mediterreense kultuur na iemand sonder identiteit, iemand sonder 'n vader wat aan hom geloofwaardigheid sou kon verleen (Van Aarde 1997:459). Sy betrokkenheid by die lot van sosiale uitgeworpenes, veral vroue en kinders, is ongewoon en beslis onkonvensioneel vir die tyd waarin hy leef.

Van Aarde verskaf 'n sosiaal-wetenskaplike verduideliking vir die historiese figuur van Jesus wat op God as sy Abba vertrou, wat die konvensionele patriargale waardes ondermyn en wat sorg vir vroue en kinders, die mense wat aan die rand van die samelewing beweeg het. In Galilea, ten tye van die koninkryk van die Herodes-familie, was die ondersteuningsbasis van families van (dikwels grondlose) kleinboere besig om stelselmatig te verwater vanweë politieke en ekonomiese probleme (Van Aarde 1997:462; vgl ook Horsley [1989] 1994). Dit is gedurende hierdie tyd dat Jesus God se koninkryk in gelykenisse en gebede voorstel as 'n vader se huishouding waarin daar op 'n anti-hiërargiese en a-patriargale wyse omgesien word na hulle wat hierdie sorg sou moes ontbeer.

\section{JESUS EN DIE NUWE FAMILIE}

Die vroegste Christene se interpretasie van Jesus se geboorte getuig daarvan dat Jesus se koms gesien is as 'n ommekeer van konvensionele waardes. In die loflied van Maria (Luk 1:46-55), gemodelleer op die lied van Hanna (1 Sam 2:1-10), word God se werk ter wille van die swakkes en die nederiges besing. Die hoogmoediges, maghebbers en rykes word gestroop van hulle magsposisies, terwyl die geringes en behoeftiges God se seẻn ontvang. Die werking van God se Gees word dus gekenmerk deur die ommekeer 
van kulturele waardes. Kulturele waardes word vervang met die waardes van die koninkryk van God (vgl Jacobs-Malina 1993:350 — (kyk ook Mark 10:42-45).

Jesus self was nie verbonde was aan 'n aardse vader nie en self het Hy ook nie 'n aardse vader geword nie. Hy staan dus buite wat die patriargale sisteem verwag van 'n eerbare man. Om op hierdie wyse nie te voldoen het aan die verwagtings van die patriargale sisteem nie, en om in die openbaar binne die konteks van kleinboerdery op te tree in die rol van 'n vrou deur te bedien, die onbelangrikste (die laaste) plek in te neem, kon 'n man sy eer kos (Jacobs-Malina 1993: 2). In die lig van hierdie tipies vroulike gedrag tipeer Dianne Jacobs-Malina (1993) Jesus se optrede as duidelik antipatriargaal. Sy stel dat Jesus se optrede in die samelewing en met sy dissipels, asook die beelde en voorbeelde wat Hy gebruik het in sy verkondiging, meer ooreenstem met die rol van die vrou as met dié van die patriargale vader.

Jacobs-Malina (1993:2) se tese is dat Jesus die rol vervul van 'n vrou wat die belange van die afwesige vader dien en bevorder. Sy gaan van die standpunt uit dat God in Jesus se verwysingsraamwerk die 'afwesige vader' is. Hoewel Jesus wel die patriargale familie as analogie vir die koninkryk van God gebruik (Meier 1991:353, nota 5; Van Aarde 1997:456; Horsley 1994:122), het Hy self nie gekonformeer met die aardse patriargale familiesisteem nie. Hy het nie die verwagte rol van 'n oudste seun, en later as patriarg in eie reg, vervul nie. Vir Jesus was nie die familiehoof nie, maar God die vader in wie gelowiges ingebed is (kyk Osiek 1997:809). Alle gelowiges, ongeag sosiale status, ras, geslag of ouderdom is deel van God se familie en word deur God versorg en beskerm.

Met verwysing na Jesus se verhouding met sy ma, Maria, formuleer die bekende Jesus-navorser, John Dominic Crossan (1994:59), Jesus se negering van patriargale chauvinisme soos volg:

The family is a group to which one is irrevocably assigned, but in the Gospel of Thomas 55 and Mark 3:31-35], that given grouping is negated in favor of another one open to all who wish to join it. And the reason those groups are set in stark contrast becomes more clear by the third example [ $Q$ Gospel in Luke 11:27-28]. A woman declares Mary blessed because of Jesus, presuming, in splendid Mediterranean fashion, that a woman's greatest honor derives from mothering a famous son. But that patriarchal chauvinism is negated by Jesus in favor of a blessedness open to anyone who wants it, without distinction of sex or gender, infertilty or maternity. 
Die lede van die nuwe familie, oftewel die koninkryk van God, se lewens word nie bepaal en georden deur kulturele waardes soos eer, wraak, mag, segregasie, goedheid, eksklusiwiteit, onpersoonlikheid of emosionele afstand tussen mense nie. Sosiale kategoriee wat mense beperk en inperk, soos geslag, ras, godsdiens, rykdom, ouderdom, status, siekte of gesondheid is in die nuwe bedeling nie meer bepalend vir mense se waarde, plek en optrede in die samelewing nie. Al hierdie dinge plaas 'n beperking op God se werk ten behoewe van God se kinders (Jacobs-Malina 1993:50). Die patriargale familiesisteem het van die vrou 'n randfiguur gemaak het in sowel die samelewing as die familie - nie gesien nie en ook nie gehoor nie, 'n onvoltooide persoon met semi-slaafstatus.

Jesus herstruktureer die familie rondom God as Vader, en daarmee vind 'n ommekeer plaas, nie net van geslagsrolle nie, maar ook van die waardes wat kulture onderling beskou as wenslik en aanvaarbaar. Jacobs-Malina (1993:64) meen:

There is every reason to believe that Israel's rejection of Jesus was necessitated by the maintenance of a patriarchal social system which would have deplored Jesus' negation of male honor as the central social value, his summons to service rather than control, and his unflagging criticism of Israel's purity laws which maintained discrimination and segregation as the will of God.

In patriargale samelewings word geglo dat 'n man se teenwoordigheid noodsaaklik is, sodat die vrou nie skande oor die familie bring nie. As die man dus afwesig is, moet die vrou selfs nog meer as andersins streng hou by hoe die man dinge wil hê. Die samelewing hou haar nog skerper dop as wanneer haar man tuis is. Op die manier bly die pa teenwoordig by sy vrou en kinders, al is hy fisies afwesig. Die vrou tree dan op as sy gemagtigde en moet sorg dat sy belange in sy afwesigheid beskerm word. Dit is die rol wat Jacobs-Malina (1993:2) meen Jesus vervul in die nuwe familie. God is die fisies afwesige vader en Jesus behartig God se belange op so 'n wyse dat God steeds teenwoordig bly by sy familie. Hoewel ek nie meen dat Jacobs-Malina se tese in verband met God as 'afwesige vader' in die visie van Jesus sondermeer as histories in alle opsigte aanvaar kan word nie, wys sy aspekte in die lewe van Jesus en in die getuienis van die skrywers van die Nuwe Testament uit wat inpas by wat as die Jesus-saak beskryf kan word. Die res van my uiteensetting hieronder steun veral op hierdie aspekte. 


\subsection{Die hersosialisering van lede van die nuwe familie}

Een van die take van die vrou was om die lede van die huishouding te sosialiseer om hulle plek in die samelewing te kan inneem. Hulle moes van haar die waardes van die samelewing leer, asook watter optrede en gedrag aanvaarbaar en korrek in die samelewing sou wees. Jesus speel hierdie rol in die nuwe familie van God. Hy leer die gelowiges wat die familie van God binnekom, wat dit beteken om lid van God se huishouding te wees. Dit is egter duidelik dat Jesus ander waardes voorhou as die heersende patriargale waardes van die samelewing (vgl Jacobs-Malina 1993:22). Die waardes van die koninkryk van God kom nie ooreen met die sosiale en kulturele waardes van Jesus se tyd nie. Jesus vervul in die nuwe familie die rol om die lede van die familie te sosialiseer: om hulle te leer wat waardevol vir die lede van die nuwe familie is, wat goed en reg is volgens die wil van hulle Vader, God. 'The church became the substitute for the family, ascribing to itself all the claims to loyalty and dedication that the traditional family imposed on its members, but at the same time taking upon itself the obligation to provide for each member all the kinds of support that anyone had a right to expect from family' (Osiek 1997:810).

Die ommekeer van sosiale waardes kom sterk na vore wanneer Jesus die waardes van die nuwe familie verskuif vanaf uiterlike gedrag wat deur die samelewing gesien en goedgekeur moet word, na die hart van die mens. Die samelewing in Jesus se tyd het wel innerlike waardes beklemtoon, naamlik om jouself te gee, om geredelik te vergewe, om onvoorwaardelik te gee, om nederig te wees en om kuis op te tree. Hierdie waardes en gedrag was egter in daardie kultuur net van vroue verwag. Jesus neem hierdie verwagtings van die samelewing ten opsigte van vroue en maak dit van toepassing op alle lede van die inklusiewe huishouding van God. Hierdie 'vroulike' optrede hou Hy voor as gedrag wat God goed en wenslik vind. Jesus hersosialiseer die persone wat by Hom aansluit van binne af uit (Jacobs-Malina 1993:70). Jesus wyk op die volgende punte af van die heersende patriargale gedrag, konformeer met die waardes en gedrag van vroue in sy kultuur en verwag van sy volgelinge om dieselfde te doen:

\subsection{Beskerm die eer van die vader}

Vanuit 'n Westerse perspektief kom dit vreemd voor dat Jesus mense genees en hulle dan beveel om niks te sê nie. 'n Mens sou verwag dat Jesus dit sou goed vind dat die boodskap wat Hy oor die koninkryk van God te verkondig gehad het, so vinnig moontlik versprei sou word. Jesus het egter nie volgens moderne kriteria gewerk nie; ook nie volgens die patriargale kriteria van sy tyd nie. Hy genees die melaatse en beveel hom om dit nie bekend te maak nie. Hierdie optrede is nie kenmerkend vir 'n man in daardie kultuur wat sy eer verkry, uitbrei of verloor in die openbaar nie. 'n Man sou baie 
seker wou maak dat enige optrede wat vir hom eer kon verdien, duidelik sigbaar en bekend sou word sodat die mense dit kon bevestig, want dan eers sou dit volgens die reëls van die kultuur vir hom waarde gehad het. Sonder sigbaarheid en bevestiging deur die mense, sou daar nie tot sy eer toegevoeg kon word nie.

Volgens Jacobs-Malina se tese dat Jesus se optrede gemodelleer word op dié van die vrou van die afwesige patriarg, sou dit egter die aangewese manier van doen wees. Die onberispelikheid van God se huishouding en God se eer sou vereis dat die optrede van die persoon wat die huishouding behartig in die Vader se afwesigheid, nie 'n openbare skouspel word nie. Die openbare sfeer is die man se arena. Die vrou, daarenteen, moet uiters korrek en onopsigtelik optree in die openbaar om nie skande oor die patriarg en die familie te bring nie (kyk Stegemann \& Stegemann 1995:315-319). As sy in die openbaar aandag trek, verloor die man in wie sy ingebed is, sy eer (JacobsMalina 1993:12, 13). Dit is dus duidelik dat Jesus nie soos 'n man in die patriargale sisteem optree nie, maar veel eerder die optrede en gedrag van die vrou vertoon.

\subsection{Gee onvoorwaardelik}

In die patriargale sisteem is wederkerigheid ' $n$ belangrike beginsel wanneer dit kom by mense buite die onmiddellike familiekring. As daar ' $n$ wanbalans is tussen wat ' $n$ man gee en wat hy terug ontvang, verloor hy eer. Bruce Malina (1993:112) stel dit so: 'Behavior at this boundary, horizontally considered, entailed reciprocal obligations with one's colleagues.' Wat mans betref, word daar nie vryelik gegee nie. As 'n vrou egter terughou en nie vryelik, onvoorwaardelik en onbeperk bly gee nie, verloor sy haar vroulike eer. Dit is egter nie slegs 'n verlies van die oomblik vanweë die spesifieke insident nie. As sy te enige tyd nie gee soos van haar verwag word nie, verloor sy ook al die eer wat sy tot in daardie stadium vir haarself verdien het. 'n Vrou kan dus nooit ophou gee nie. Net mans kan weier om te gee. Trouens, 'n man moet soms weier om te gee of om te vergewe, anders kom sy manlike eer in die gedrang (Jacobs-Malina 1993:18).

Die evangelies getuig egter dat Jesus onder mense gegee en gewerk het sonder om iets van hulle terug te verwag. Dit is hoe ' $n$ vrou in daardie kultuur sou optree. Jesus het gegee soos 'n vrou en nie soos 'n man in die kultuur van sy tyd nie. Jesus het dit duidelik gestel dat die kriterium van onvoorwaardelike gee die waarde is wat geld vir die familie van God. Hy kontrasteer die skrifgeleerdes wat eer soek van mense (terwyl hulle weduwees uitbuit en God om die bos probeer lei met lang gebede) met die weduwee wat alles gee wat sy het (vgl Mark 12:13-44). Die kriterium van die koninkryk van God is anders as die van die kultuur van die tyd. In die familie van God gaan dit nie om ryk of belangrik wees nie. Dit gaan nie om eer en status nie. Waar dit by God 
se huishouding kom, is die standaard om alles te gee. Dit is die standaard wat in die kultuur aan vroue gestel word ten opsigte van gee (Jacobs-Malina 1993:22, 32).

\subsection{Lyding}

In Markus 8:27-30 lees ons dat Petrus niks wou hoor oor Jesus se lyding nie. Die kultuur van die tyd het voorgekryf dat daar in die manlike rolle geen plek is vir eerlose lyding en vernedering nie. Die rolle wat die samelewing-aan die vrou toeken, laat egter geen ander keuse as lyding en vernedering nie. Vroue se lyding word ook nie beskou as heroies nie. Die vrou is nie veel meer as 'n slaaf in haar man se familie nie. Die vrou wat haar lewe waag in kindergeboorte, word nie geprys as besonder moedig nie. Maar die vrou wat nie seuns in die wêreld bring nie, word wel gedoem tot skande. Jesus leer die lede van die familie van God dat lyding vir hulle, soos vir die moeders en dogters in hulle kultuur, 'n intrinsieke deel van hulle rol sou wees (Jacobs-Malina 1993:24).)

\subsection{Grootheid/diens}

Markus 9:33-41 berig oor 'n vraag wat onder die dissipelbroers (seuns van Sebedeus) ontstaan het: Wie is die grootste in die koninkryk van God? In die samelewing van daardie tyd was grootheid gekoppel aan mag, dominansie, beheer, rykdom, aansien, status, eerste wees en in die voorste gestoeltes sit. Jesus het ook hierdie waardes omgekeer en die lede van God se familie hersosialiseer. In die koninkryk van God is die belangrikste dié een wat laaste is en die een wat almal se dienaar is. In die patriargale familie kry die man en die gaste eerste kos, aandag en bediening. Daarna kry die kinders kos, en die vrou eet wat oorbly. Die ideale vrou volgens die kultuur is dié een wat bediende is vir almal, die een wat laaste in ag geneem word. Sulke gedrag verdien vir 'n vrou 'n mate van eer en status volgens die samelewing se norme.

Kinders word net so min geag soos vroue in die patriargale sisteem. Die kinders is vroue se verantwoordelikheid. Mans het niks met die opvoeding van klein kinders te make gehad nie, en het ook geen verantwoordelikhede gehad spesifiek ten opsigte van kinders nie. Wanneer Jesus met kinders te doen het, reflekteer die dissipels se opmerkings die norme van die samelewing. Hulle wil nie hê dat Jesus gehinder moet word met sulke onbelangrike mense nie. Wanneer Jesus egter praat oor die waardes van die koninkryk, neem $\mathrm{Hy}$ 'n kind en sê: 'Elkeen wat so 'n kindjie in my Naam ontvang, ontvang My; en elkeen wat My ontvang, ontvang nie net vir My nie, maar cok vir Hom wat My gestuur het' (Mark 9:37). Anders as in die manlike kultuur van die tyd, verbind die ontvang van die kind 'n mens met God, volgens Jesus se norme. 
Kinders is normaalweg gesien as persone wat eers gesosialiseer moet word voordat hulle 'volwaardig' mense kon wees. Een van die redes waarom vroue in die Mediterreense kultuur minderwaardig verklaar was, is omdat hulle liggaam, energie en lewe draai om die voortbring en grootmaak van kinders (Jacobs-Malina 1993:26). Ook hierdie waardes het Jesus omgedraai. Die kind is volgens Hom mér geskik vir die koninkryk van God as die reeds gesosialiseerde volwassene. Die kind dien trouens vir die volwassene as 'n voorbeeld (kyk Matt 18:1-5; 19:14). Volgens kulturele maatreëls word seuns vermaan om groot te word en hulle soos 'n man te gedra. In die koninkryk van God word mans vermaan om hulle in die posisie van 'n kind te plaas voor God die Vader en die voorsiener. Kindskap is volgens Jacobs-Malina (1993:28) die enigste stadium in die lewe van die Mediterreense persoon waar voorskrifte op grond van geslag nie die manlike en vroulike van mekaar skei nie. Dit op sigself was 'n aanduiding van die kind se onvolwaardige menswees volgens dié kulturele kode.

\subsection{Privaat (huishouding) en openbaar}

Die grens tussen privaat (tradisioneel die terrein van die vrou) en openbaar (tradisioneel die terrein van die man), word weggevee in God se huishouding. God sien wat in die private sfeer sowel as in die openbaar, gebeur. God weet alles. God ken die hart van die mens, die gesindheid. Die kultuurnorm van daardie tyd was dat alles wat waarde het net in die openbaar deur die mans in die samelewing bepaal kon word. Jesus keer hierdie waarde om. Die gelykenis van die lamp (kyk Mark 4:21-25) stel dit duidelik dat alles wat verborge is, aan die lig sal kom.

'n Voorbeeld van hoe Jesus soos 'n vrou in die private domein optree, eerder as soos ' $n$ man in die openbare terrein, is sy hulp aan die weduwee van Naïn (kyk Luk 7: 11-17). In die kultuur van sy tyd is die vrou se lewenskwaliteit afhanklik van manlike familielede. 'n Vrou sonder enige manlike familie se vooruitsigte is donker. Hoewel hierdie vrou niks van Jesus vra nie, kom Hy uit sy eie om haar te help. Hy sien haar nood raak en gee aan haar seun, en dus ook aan haar, die lewe terug. Jesus tree hier op volgens die reël van die private domein, waar hulp gegee en ontvang word sonder die komplekse stelsel van beperkings wat die openbare verhoudings van mense van verskillende huishoudings bepaal het.

Vir God se familie is familiewaardes nader aan God se wil as die waardes wat in die antieke midde-Oosterse kultuur vir mans in die openbaar gegeld het (Jacobs-Malina 1993:49). Voedselvoorbereiding en -bediening is tradisioneel die taak van die vrou. In die patriargale sisteem van Jesus se tyd was daar streng regulasies oor wie saam met wie mag eet. Dit het onder andere ten doel gehad om die sosiale hiërargie te handhaaf. In die vertellings waar Jesus die skare voed (Mark 6:30-52) verander Hy die openbare 
ruimte in 'n huishoudelike ruimte. Die gesamentlike gebruik van voedsel verander vreemdelinge in lede van die huishouding of vriende van die familie (Jacobs-Malina 1993:21). So het Jesus volgens hierdie vertellings die sosiale grense oorskry en het Hy die grens tussen privaat/huishoudelik en openbaar verwyder. In die openbaar het $\mathbf{H y}$ almal verwelkom, vriend en vreemdeling, om met Hom tafelgemeenskap te hê, en soos 'n vrou het Hy gesorg vir die voedsel.

Markus 7:1-24 berig dat Jesus en sy dissipels met ongewaste hande geëet het. Daarmee is die reinheidsvoorskrifte ortree. Met hierdie gebaar, en die daaropvolgende gesprek, toon Jesus volgens Markus aan dat die belangrikste ruimte nie die uiterlike openbare is nie, maar die private en innerlike. Aangesien eer in die openbaar verkry, verloor of vermeerder word, gaan dit direk in teen die patriargale stelsel wat die hoogste premie plaas op eer. Jesus verskuif die fokus na die private, innerlike nuimte. Volgens Hom behoort die uiterlike nie die innerlike te beheer nie, maar andersom. Dit is die harte van mense wat die openbare lewe vorm en tot stand bring. Die klem lê nie op sosiale beheer en kontrole nie, maar op die persoonlike bekering tot die wil van God. As die persoonlike ruimte op dié manier reg gestel is, kan die openbare lewe volgens die waardes en norme van God se koninkryk ingerig word en hierdie nuwe normstelsel weerspieèl (Jacobs-Malina 1993:24).

\section{7 'n Ander soort vader}

Jesus verander die beeld van God, sowel as die beeld van die vader van die familie. Omdat 'n vader se eer van soveel belang is, het die vader die reg om genadeloos op te tree teenoor 'n seun wat sy eer en waardigheid in die gedrang bring. 'n Seun wat nie konformeer aan die standaarde van goeie gedrag volgens die voorskrifte van die samelewing nie, doen sy vader se reputasie skade aan. As dit blyk dat die vader nie genoegsaam beheer or sy seun kan uitoefen nie, kry sy eer 'n knou. Die gelykenis oor die verlore seun is 'n goeie voorbeeld van 'n seun wat sy pa se eer aantas. Maar God, die vader in die storie, tree heeltemal anders op as wat 'n patriarg in Jesus se tyd met só 'n seun sou doen. God is bly om die seun weer te sien en verwelkom hom terug sonder enige voorwaardes, sonder enige begeerte tot wraak en straf waarmee die vader sy eer sou moes beskerm. Jesus verkondig 'n God wat anders optree as die streng, straffende, oordelende God waarvan 'n mens so dikwels in die Ou Testament lees (Jacobs-Malina 1993:45, 47). Die eer van die vader buig in Jesus se beeld van God die knie voor onvoorwaardelike liefde en aanvaarding van mense. Vir die samelewing van Jesus se tyd was dit 'n vreemde waarde. 


\subsection{Geen grense in die familie van God}

Grense speel 'n groot rol by die volk Israel. Dit hou verband met hulle konsep van heiligheid. Om heilig te wees, beteken om afgesonder te wees vir God. Die volk Israel moet dus afgesonder bly van ander volke. Grense moet gehandhaaf word. Binne die volk self handhaaf die reinheidsisteem grense tussen verskillende soort mense. Die reinheidsvoorskrifte klassifiseer mense en dinge in verskillende grade van reinheid. Dié wat meer heilig is, moet hulle afgesonder hou van wat minder heilig of onrein is, sodat hulle eie reinheid nie in die gedrang kom nie. Vroue, mense met 'n siekte of gebrek en nie-Jode is almal mense van wie Joodse manne hulle, volgens die grense wat bepaal is in die reinheidsideologie, moet afsonder en 'n skerp skeiding moet handhaaf. Jesus sluit egter vroue in die familie van God in.

Die verhaal van Marta en Maria (Luk 10:38-42) bevestig die waarde wat Jesus aan vroue toeken. In hierdie verhaal mag 'n vrou, net soos die mans, aan Jesus se voete sit en van Hom leer. Die diens wat vroue lewer word nie deur Jesus in die verhaal ontken nie, maar vroue moet hulle rolle aanpas (onafhanklik van die samelewing se verwagtings) om te pas by die eise van 'n huishouding wat rondom God georganiseer is. In so 'n huishouding is elke lid, man, vrou en kind ingebed (Jacobs-Malina 1993:50). Lukas (7:36-50) berig dat Jesus 'n 'sondige' vrou toelaat om Hom aan te raak. Die vrou het Jesus se voete gewas, nadat die gasheer versuim het om dit te doen. Jesus verklaar dat die vrou vergewe is op grond van haar baie liefde. God vereis volgens Lukas nie dat daar saam met berou, herstel en verandering ook nog straf bygevoeg moet word nie. Volgens Jacobs-Malina (1993:50) is dit 'n menslike vereiste, nie 'n Goddelike een nie. Jesus oortree 'n reel van die samelewing deur 'n vrou op die sabbatdag te genees (kyk Luk 13:10-17). Weer eens beklemtoon Hy duidelik met sy optrede dat alle mense vir Hom belangriker is as wette, reels en die voorskrifte van die samelewing.

Jesus sluit nie net vroue in by die familie van God nie, maar ook nie-Judeërs. Volgens Lukas 17:11-19 was daar onder die tien melaatses wat Jesus genees het ook 'n Samaritaan. Hy is dan ook die enigste een wat terugkom om Jesus te bedank en God te prys. God se corvloedige genade is dus nie net beskikbaar vir die Judeërs nie, maar ook vir die Samaritaanse volk wat Israel altyd beskou het as afvallig en minderwaardig. Volgens die Talmoed (Kiddushin 75a, iv, 3) word die Samaritane gereken onder 'the people of uncertain condition [i e with whom one may not marry]: those of unknown parentage, foundlings and Samaritans.' In die Mishna (Nidda vii, 4) word gesê: 'The Samaritan women are menstruous from the cradle' (kyk Montgomery [1907] 1968). Hierdie oortuiging kan moontlik lig werp op Jesus se genesing van die twaalfjaarlange, menstruerende vrou en die opwekking van die twaalfjarige dogter (kyk Luk 8:42) van 
Jaïns (kyk Mark 5:21-43). Die enigste voorwaarde vir optrede van God in 'n mens se lewe is klaarblyklik dat die persoon gewillig moet wees om dit te ontvang (JacobsMalina 1993:51, 2).

\subsection{Mag of mense}

Jesus gebruik soms die bekende beelde van konings en regeerders in sy gelykenisse. Mag, wat inherent deel is van die patriargale sisteem, word egter nooit vir Jesus die norm vir die koninkryk van God nie. Juis deur die beelde van maghebbers te gebruik, stel Jesus die kontras met die koninkryk van God (vgl Mark 10:42-43). Direk op die gelykenis van die muntstukke in Matteus 25 volg die sogenaamde 'profetiese rede' waarin Jesus voorgestel word as die Seun van die mens wat weer sal kom. Die meester in die gelykenis wil weet hoeveel rente sy geld verdien het. Die Seun van die mens wil weet hoe die mense in sy afwesigheid behandel is. 'While cultures declare that the need to please elites eclipses the concerns for those who are poor, outcast, powerless, etc., caring for others is the kingdom's standard against which all will be judged by the Son of man' (Jacobs-Malina 1993:45).

Die saligsprekinge vra van dissipels gedrag wat vir mans sowel as vroue geld. Hier is geen statusverskil ter sake nie. Die veragtes in die samelewing, die armes en nederiges wat oor geen sosiale mag beskik nie, is die mense wat oop voor God en afhanklik van God kan lewe omdat hulle behoort tot God se koninkryk. Aan die waardes wat Jesus voorhou as die waardes van die koninkryk van God, lyk dit asof Jesus veel meer aansluiting vind by die optrede en gedrag wat van die vrou in die patriargale samelewing verwag word. Patriargale waardes hou verband met mag, status, eer en posisie.

\section{WAAROP DIT AANKOM}

\subsection{Die koninkryk van God}

Kultuur bestaan uit ' $n$ sisteem van simbole wat waarde en betekenis toeken aan die rolle, optrede en gedrag van mense (kyk Dreyer 1999:50-51). Kultuur vorm die sosiale wêreld van die spesifieke groep mense. Al die lede van die groep leef dus vanuit hierdie gedeelde stel waardes en betekenisse. Die kultuur en sosiale sisteem waarbinne iemand leef, word gewoonlik nie bewustelik beleef nie. Onbewustelik bepaal dit egter die persoon se beskouing van die werklikheid. Dit bring mee dat mense wat binne 'n kultuur leef, die waardes van die kultuur nie maklik bevraagteken nie, maar dit gewoon aanvaar as hoe dit moet wees; dit is hoe dit hoort. Vir vroue beteken dit dat hulle die 
rolle en gedrag wat die kultuur aan hulle voorskryf, gewoonlik aanvaar as vanselfsprekend, korrek en soos dit hoort. Vroue word van kleins af geleer om hierdie waardes so te aanvaar. Wanneer vroue.volwasse word, ontvang hulle die verantwoordelikheid om kinders in hierdie waardes te sosialiseer. Vroue is dus altyd medewerkers aan die voortsetting van die sisteem van waardes en betekenisse van 'n kultuur.

In 'n patriargale sisteem is vroue egter nie die mede-skeppers van die waardes en betekenisse van die kultuur nie. In 'n patriargale sisteem is 'n vrou nie 'n volwaardige persoon met die regte en voorregte wat aan volwaardige volwassenes in die samelewing toegeken word nie. Die vader/familiehoof is die volwaardige persoon met die regte en voorregte. Die vrou in die patriargale sisteem funksioneer in 'n ondersteunende, dienende hoedanigheid. Die samelewing tipeer haar waarde as minder as dié van 'n man. Die rolle wat vir haar voorgeskryf word, is dienende rolle. Nogtans aanvaar die vrou hierdie waarde- en roltoekenning as goed, reg en vanselfsprekend, omdat die kultuur haar van kleins af so geleer het. Aangesien hierdie kondisionering op 'n onbewuste vlak plaasvind, word dit ook onbewustelik geinternaliseer en die uiteinde is die aanvaarding dat dit maar so hoort. Daarom help vroue in die patriargale sisteem om by hulle seuns 'n gevoel van eie-waarde en by hulle dogters 'n gevoel van minderwaardigheid in te skerp. Vroue in 'n patrargale sisteem leer hulle seuns dat hulle regte en voorregte kan opeis op grond van hulle geslag, en hulle dogters dat hulle geen regte het nie, maar lewenslank in diens sal wees van die een of ander patriarg.

Twee dinge staan voorop wanneer daar na Jesus se gebruik van die konsep 'koninkryk van God' gekyk word. Die een is dat dit 'n skokuitwerking by sy hoorders moes gehad het. Hy gebruik 'n konsep wat uitdrukking is van die hoogste vlak van patriargale hiērargie, met alles wat daarmee saamhang. Maar, in die tweede plek, herdefinieer Hy hierdie begrip. In plaas van 'n koning praat hy van 'n vader wat nie manipulerend uitbuit nie, maar sorg dra deur vir almal in die huishouding hulle 'daaglikse brood' te gee (vgl die Onse Vader-gebed: 'Ons Vader wat in die hemel is, laat u koninkryk kom ... gee ons ons dag se brood; laat ons diegene vergewe wat teen ons oortree het, omdat U ons vergewe het'). Hier is daar duidelik nie sprake van eksklusiwiteit nie - nie ten opsigte van buitestaanders nie, nie ten opsigte van kinders nie, en ook nie van geslag nie.

\subsection{Groepsidentiteit}

In die patriargale kultuur van die Ou en Nuwe Testament is daar nie veel sprake van individualiteit nie. Die belange van die groep staan te alle tye voorop. Alle magte, regte, voorregte en dienslewering is gerig op die groep. Die groep bepaal wat goed en sleg is, wat reg en verkeerd is, wie cer ontvang en eer verloor. Dit beteken dat lewens 
ingerig word om mense tevrede te stel en om die openbare mening aan hulle kant te kry. Jesus bring 'n verskuiwing aan: nie wat die mense sê nie, maar wat God wil, bepaal wat goed of sleg, reg of verkeerd is. Jesus stel dit duidelik dat 'n gelowige meer gehoorsaam moet wees aan God as aan die mense. Jesus se fokus val nie meer op wat in die openbaar gebeur nie, maar op wat in die hart en gesindheid van die mens aangaan.

Die konsekwensie wat hierdie verskuiwing vir vroue het, is dat vroue nou oor dieselfde kam geskeer kan word as mans. As die openbare lewe en die openbare mening die norm is, is daar 'n duidelike verskil tussen hoe mans en vroue lewe, hoe hulle optree en hoe hulle beoordeel word. Daar is verskillende norme vir die gedrag van mans en vroue. Daar word verskillende waardes toegeken aan die persoonskap van mans en vroue. Maar as die hart van die mens voor God ten opsigte van die mede-mens die norm is, is die gesindheid en optrede wat van die gelowige vereis word, dieselfde. Sowel die man as die vrou moet 'n positiewe gesindheid teenoor die naaste in sy of haar hart handhaaf. Sowel die man as die vrou moet die mede-mens in liefde dien, die ander se belange op die hart dra, onvoorwaardelik gee en die eie eer op die agtergrond skuif ten gunste van die beswil van die naaste.

Hierdie verskuiwing van die waardes van die koninkryk van God weg van die waardes van die patriargale sisteem, het vir die vrou tot gevolg dat sy volledig daarby ingesluit kan word. Met hierdie waardes is daar geen onderskeid tussen die waardes vir mans en die waardes vir vroue nie. Ook word daar nie verskillende gedrag in die private lewe of in die openbaar verwag van mans as van vroue nie. Die vrou beweeg dus in die koninkryk van God op gelyke vlak met mans. Die skeidings van die patriargale sisteem het weggeval. Met die verskuiwing van waardes in die familie van God, het die vrou miskien selfs ' $n$ voorsprong, want die nuwe waardes van die koninkryk is meer bekend in haar leefwêreld as in die leefwêreld van mans binne die patriargale sisteem.

\subsection{Geslagtelike a-simmetrie}

Die antieke Mediterreense samelewing verdeel die werklikheid in terme van geslag. Die waarde wat gekoppel word aan die manlike geslag, is hoog; die waarde gekoppel aan die vroulike geslag, is laag. Alles wat dus te doen het met wat vroulik is, word gewaardeer as minder belangrik, minder goed, minder heilig, minder heel. 'n Minderwaardige posisie en mindere rolle word dus aan vroue toegeken. Die skeiding tussen die manlike en vroulike rolle vorm een van die mees sentrale waardes in die tyd van Jesus. Die ongelykheid tussen man en vrou, word die analogie waarvolgens ander verhoudings in die samelewing verstaan word: minderwaardig soos 'n vrou staan ook die 
natuur teenoor die kultuur, die slaaf teenoor die meester, die onderdaan teenoor die heerser, die kind voor die ouer, die leerling teenoor die leermeester, die mens voor God.

Jesus hef hierdie skeidings, ongelykheid en die waardeverskille tussen mense op. Wat tradisioneel minderwaardig gereken word, verhef Jesus tot norm vir die koninkryk van God: wie nie soos 'n kind word nie, sal die koninkryk nie binnegaan nie. Wat vroue betref, oortree Jesus al die taboes van sy tyd: hy praat met vroue in die openbaar, laat hulle aanraking toe (selfs deur 'n vrou met bloedvloeiing wat dus onrein is), leer hulle teologie en laat hulle toe om te gaan verkondig. Jesus verhef die dienende posisie van die slaaf en die vrou tot norm vir die familie van God: almal moet mekaar dien, vir mekaar gee en mekaar se voete was. Wie laaste is, sal volgens Jesus eerste wees, en wie eerste is, laaste.

Volgens Jesus se woorde en optrede is daar nie vir vroue 'n spesiale, minderwaardige plek afgesonderd van mans nie. Almal, mans, vroue, kinders, slawe en onreines is aanvaarbaar en ingebed die nuwe familie van God. Dit gee aan alle mense voor God 'n gelyke plek, 'n gelyke status en 'n gelyke verantwoordelikheid tot diens. Mense is nie meer belangrik, meer of minder eervol en in 'n hoër posisie as ander mense nie. Net God is in die nuwe familie belangriker, heerliker en in 'n hoër posisie as mense. Maar selfs met die skeiding tussen God en die kreatuurlike wêreld het daar 'n beduidende verandering gekom. Volgens die denke van die tyd sou geen man met selfrespek die grens oorskry wat hom van vroue skei nie. So sou God ook nooit die grens oorskry na die kreatuurlike wêreld toe nie (vgl Jacobs-Malina 1993:76). Die Johannes-evangelie berig egter hoe hierdie grens wat die patriargale sisteem as vanselfsprekend aanvaar het, deur God self oorskry is: 'In die begin was die Woord daar, en die Woord was by God, en die Woord was self God .... Die Woord het mens geword en onder ons kom woon' (Joh 1:1, 14a). Jacobs-Malina wys uit dat die evangelie van Johannes die patriargale ordening van die kosmos verwerp. 'Hierarchy was inverted, disparity was bridged, separation was joined, submission was elevated and flesh bore the weight of the glory of God' (Jacobs-Malina 1993:77).

In patriargale kulture word vroue beskou as meer verbonde met die ongetemde; die natuur, die kreatuurlike en mans meer met hoër geestelike dinge. Vroue word tot die laer natuurorde gereken vanweë hulle biologiese prosesse wat te doen het met prokreasie. Vroue word gesien as minderwaardig tot mans, want mans is meer suksesvol in die menslike poging om die natuur te transendeer as vroue. 'For those religious systems where God's self-disclosure is strictly limited to revelation in the language of the particular group, this action of the Word becoming flesh was the dagger thrust into the heart of patriarchy' (Jacobs-Malina 1993:78). 


\subsection{Die huwelik}

Die huwelik is by uitstek die plek waar die vrou as randfiguur en minder-bevoorregte funksioneer. Sy word soos 'n soort besitting aangeskaf en behandel. As werker in diens van haar man se familie moet sy onverpoosd arbei en kinders baar. Sy verkry geen posisie in die nuwe familie nie en word nooit beskou as bloedfamilie nie. Sy bly altyd 'n soort vreemdeling en het geen sekuriteit nie, want haar man het die reg om van haar te skei en haar weg te stuur. Wanneer dit gebeur, is sy gedoem tot 'n onbenydenswaardige lot.

Jesus verander hierdie praktyk van die patriargale sisteem wanneer Hy alle egskeiding verbied. Hy neem dus die man se reg in die samelewing om van sy vrou ontslae te raak, weg. Man en vrou word deur Jesus gelyk gemaak wanneer Hy, wat egskeiding betref, aan hulle dieselfde regte toeken. Jesus verklaar ook dat man en vrou in die huwelik een 'vlees' sal wees. Dit beteken dat hulle, anders as in die patriargale sisteem van sy tyd, wel bloedfamilie word. Die vrou is nou nie meer 'sexual property' nie, maar 'n mede-mens. Sy moet behandel word soos bloedfamilie, soos die heel naaste mede-mens. Die man en sy familie is dan verplig om haar belange op die hart dra soos wat hulle sou doen met eie familie. Jesus verander so die posisie van die vrou binne die patriargale sisteem, huwelik en familie dramaties. Die vrou verkry nou aanvaarding, sekuriteit, en 'n volwaardige posisie van 'behoort tot' wat sy nooit tevore gehad het nie.

\subsection{Die waarde van vroue}

Die vrou word alleenlik in die patriargale samelewing aanvaar as sy konformeer met haar tradisionele ondergeskikte posisie en rolle. In die verhaal van Marta en Maria prys Jesus egter die vrou wat nie konformeer nie, maar haar soos 'n man gedra en aan sy voete sit om geleer te word. Om met 'n man in die openbaar debat te voer, is allermins aanvaarbare sosiale gedrag vir 'n vrou. Hoewel Jesus aanvanklik met besware (wat tradisioneel van 'n Israeliet verwag sou word) kom wanneer 'n Siro-Fenisiese vrou Hom versoek om haar kind te genees, laat Hy haar toe om Hom met 'n argument te oortuig.

Die moeder wat vra dat haar seuns 'n belangrike plek moet inneem in die koninkryk van God, konformeer met die norme van haar samelewing. Dit is naamlik 'n moeder se plig om alles ter wille van haar seuns te doen en vir hulle die beste te verkry, sover dit binne haar vermoë is. Maar Jesus se antwoord toon dat Hy haar korrekte, moederlike gedrag nie goedkeur nie. Sy het die norme van die koninkryk van God verkeerd verstaan. In God se koninkryk moet die wat groot wil wees, dien, en die wat eerste is, moet die slaaf wees van almal. 
Eerlose vroue, soos vroue wat nie seksueel eksklusief is nie, mag volgens die patriargale sisteem in die openbaar niks te doen hê met eerbare mans nie. Jesus steur Hom egter nie aan hierdie voorskrif nie en laat die 'sondares' toe om sy voete te salf en voer 'n lang gesprek met die Samaritaanse vrou wat al baie mans gehad het. Jesus kom uit sy eie 'n vrou te hulp wat die godsdiensleiers wil doodmaak omdat sy egbreuk gepleeg het. In die kultuur van Jesus se tyd word die vrou met die dood gestraf omdat sy oneer oor haar man en familie gebring het deur nie seksueel eksklusief te bly nie - 'n norm wat nie van mans verwag is nie. Weer eens maak Jesus dit gelyk tussen mans en vroue, sowel as tussen sondes. Uit sy woorde blyk dat hy die sonde van egbreuk ('n oortreding teen die eer van 'n man) gelyk stel met die sondes wat in die harte en lewens van die oordelende persone leef: Laat die een van julle wat 'n skoon gewete het, eerste 'n klip op haar gooi (Joh 8:7b).

In die Reformatoriese tradisie word dit as aksioma aanvaar dat die mens radikaal sondig is en nie in staat tot enige vorm van volmaaktheid nie. Dit sou dus tot gevolg hê dat alle menslike sosiale sisteme die merktekens van daardie onvolmaaktheid sal dra, dus ook die kulture waarbinne die Bybel ontstaan het, sowel as die kulture en geloofsgemeenskappe van vandag. Jacobs-Malina (1993:116) stel dit so: 'The evils from which human beings need to be delivered and the sin from which they need to be saved arise within social systems which are created and maintained at odds with the intentions of God.' Alle sosiale sisteme wat nie die waardes van God se koninkryk weerspieel nie, sal in ' $n$ meerdere of mindere mate skade doen aan die mense wat binne daardie sisteme vasgevang is, veral aan diegene wat nie seggenskap het in die ontwerp van die sisteem of die moontlikheid het om persoonlike mag uit te oefen binne die sisteem nie.

Die doel van alles wat God gemaak het, is om te kom tot die volheid van wat dit bedoel was om te wees. Volgens Jacobs-Malina (1993:116) is die kategorieë mag, eer en gehoorsaamheid hier nie tot veel hulp nie. Jesus werk met die genesing en herstel van mense. Wat menslike heelheid en groei in die wiele ry, beskou Hy as teen die bedoeling van God. Elke individu, familie of gemeenskap het die keuse om hulleself te organiseer rondom die waardes en standaarde van die kultuur waarbinne hulle leef, of hulle kan deel word van God se huishouding. Bekering sou dan wees wanneer mense en groepe hulle telkens weer verbind tot die veranderings wat nodig is om te lewe soos lede van God se huishouding. Bekering vereis 'n bewustelike ommekeer van waardes. Bewus wees van die Jesus-saak is vir die Christen voorwaarde wanneer evangeliese waardes nagestreef wil word (kyk Van Eck 1995: 372-373, nota 29). 


\section{Literatuurverwysings}

Atkins, R A 1991. Egalitarian community: Ethnography and exegesis, with a foreword by Mary Douglas. Tuscaloosa: The University of Alabama Press.

Bassler, J 1982. Divine impartiality: Paul and a theological axiom. Chico, CA: Scholars Press. (SBL Dissertation Series 59.)

Borg, M J [1994] 1995. Als met nieuwe ogen: De historische Jesus en waar het op aan komt in het geloof van vandaag, vertaal deur P Ros. Meinema: Zoetermeer.

Bultmann, R [1960] 1965. Das Verhältnis der urchristlichen Christusbotschaft zum historischen Jesus. Vierte Auflage. Heidelberg: Carl Winter, Universitätsverlag. (Sitzungsberichte der Heidelberger Akademie der Wissenschaften Philosophischhistorische Klasse 3.)

Corley, K E 1997. Gender and class in the teaching of Jesus: A profile. Unpublished paper presented at the Jesus Seminar, Santa Rosa (CA), Fall 1997.

Countryman, L W [1988] 1989. Dirt, greed and sex: Sexual ethics in the New Testament and their implications for today. Second printing. Philadelphia: Fortress.

Crossan, J D 1992. Jesus and the leper, in The looking glass: Essays in celebration of a precursor for Robert F Funk. Forum 3/4, 177-190.

1994. Jesus: A revolutionary biography. San Francisco: HarperSan Francisco.

Dodson Gray, E 1982. Patriarchy as a conceptual trap. Wellesley, MA: Roundtable Press.

Dreyer Y, 1998. Pastorale interaksie met vroue: 'n Prakties-teologiese begronding. DD-proefskrif, Fakulteit Teologie (Afd A), Universiteit van Pretoria.

- 1999. Die personaliteit van vrou-wees binne die Mediterreense kultuur. HTS 55/1, 48-69.

Funk, R W 1996. Honest to Jesus: Jesus for a new millennium. San Francisco: Harper Collins. (A Polebridge Book.)

Funk, R W (and The Jesus Seminar) 1998. The acts of Jesus: What did Jesus really do? San Francisco: HarperSanFrancisco. (A Polebridge Book.)

Funk, R W \& Hoover, R W 1993. The five gospels: A search for the authentic words of Jesus. New translation and commentary. New York: Macmillan Publishing Company. (A Polebridge Book.)

Hock, R F 1995. The infancy gospels of James and Thomas. Santa Rosa, CA: Polebridge Press. (The Scholars Bible.)

Horsley, R A [1989] 1994. Sociology and the Jesus movement. Second edition. New York: Continuum. 
Malina, B J [1981] 1993. The New Testament world: Insights from cultural anthropology. Revised edition. Louisville, KY: Westminster/John Knox.

Meier, J P 1991. A marginal Jew: Rethinking the historical Jesus, Vol one: The roots of the problem and the person. New York: Doubleday.

Jacobs-Malina, D 1993. Beyond patriarchy: The images of family in Jesus. New York: Paulist.

Klassen, W 1984. Musonius Rufus, Jesus, and Paul: Three first-century feminists, in Richardson, P \& Hurd, J C (eds), From Jesus to Paul: Studies in honour of Francis Wright Beare, 185-206. Waterloo, Canada: Wilfrid Laurier Press.

Metzger, B M 1971. A textual commentary on the Greek New Testament. London: United Bible Societies.

Montgomery. J A [1907] 1968. The Samaritans: The earliest Jewish sect. Their history, theology, and literature. New York: KTAV Publishing House.

Osiek, C 1997. Jesus and cultural values: Family life as an example. HTS 53/3, 800814.

Stegemann, E W \& Stegemann, W 1995. Urchristliche Sozialgeschichte: Die Anfange im Judentum und die Christusgemeinden. Stuttgart: Kohlhammer.

Van Aarde, A G 1997. Social identity, status envy and Jesus' Abba. Pastoral Psycho$\operatorname{logy} 45 / 6,451-472$.

- [1998a]. Fatherless in Galilee: The search for Jesus child of God. Beplan om te verskyn in 1999.

- 1998b. Jesus' father: The quest for the historical Joseph. HTS 54/1 \& 2, 315333.

Van Eck, E 1995. Galilee and Jerusalem in Mark's story of Jesus: A narratological and social scientific reading. Pretoria: University of Pretoria. (HTS Supl 7.) 